\title{
The Potential For Making Handicraft Products Using Corn Husk Fiber As An Alternative Raw Material
}

\author{
Ani.M Hasan ${ }^{1}$, Amir Halid $^{2}$, Hasdiana ${ }^{3 *}$ \\ Biology, Faculty of Mathematics and Natural Sciences, Universitas Negeri Gorontalo \\ ,Gorontalo, Indonesia ${ }^{1}$ \\ Agribusiness, Faculty of Agriculture, Gorontalo Universitas Negeri Gorontalo, Gorontalo, \\ Indonesia ${ }^{2}$ \\ Fine Arts Education, Faculty of Engineering, Universitas Negeri Gorontalo, Gorontalo, \\ Indonesia ${ }^{3}$

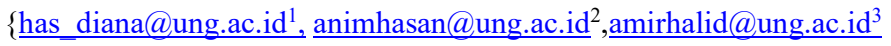

\begin{abstract}
This study offers an alternative raw material that has gone through a standardized test process for handicraft needs. The need for handicraft raw materials is increasingly varied so that tests are carried out on materials that have the potential to become alternative materials for crafts that are easily obtained in our environment. This includes sweet corn husks in Gorontalo Province, Indonesia. Provinces that have abundant maize production. This research is using experimental method. The research was conducted in three stages, namely the first stage: identification of the characteristics of the corn husk through a tensile strength test, the second stage: processing of corn husks using weaving techniques and the third stage of the product manufacturing process. The conclusion of this study shows 1 ). Corn husk which can be used as raw material for sweet corn husk handicraft products, 2). After soaking in $\mathrm{CH}^{3} \mathrm{COOH}$ for 45 minutes and drying process for 3 hours, the color of the corn husks will be lighter and the strength becomes $3.58 \mathrm{~g} / \mathrm{tex}, 3)$. Can be processed into handicraft products especially into wallets.
\end{abstract}

Keywords: Corn husk; Fiber; Raw material; Weaving; Handicraft.

\section{Introduction}

Corn has long been a superior product in Gorontalo, the trend of the performance of corn production continues to increase. It is proven that the maize production in Gorontalo Province, which increased $7.58 \%$ in 2014 compared to production in 2013, was 719,787 tons. (Gorontalo Province BPS, 2014: 16) ${ }^{\mathrm{i}}$ Increased corn production from Gorontalo corn farmers continues to increase, where from the total production of only 692 thousand tons in 2016, to 1.5 million tons in 2018. Corn has many advantages beside as people daily needs and also can be process to some products such as corn sticks, corn oil, corn starch, poultry feed, fish feed, and other function as food. In addition, corn grain can process for a variety 
of products, corn waste can make variety of products such as corn waste into ruminant feed, corn waste into organic fertilizer, corncob into charcoal, and corn husk can process become flower, dodol, the basic material of clothes, table cloth and some of unique products.

ii As a superior product of Gorontalo, of course, the production of shelled corn has increased the income of farmers and entrepreneurs in the marketing sector of shelled corn. However, the increase in income from shelled corn production has not been able to improve the welfare of the community because there is no added value from the processed product industry. Therefore, innovation during the C19 pandemic at this time urgently needed the presence of a small-scale industry that could absorb informal workers ranging from the chain of raw maize preparation, distribution, processing industry, packaging and labeling, health and halal standardization, market and marketing of good processed products. directly as well as by online marketing and up to the end customer.

In this case, it is hoped that it can develop from one innovation in product processing to producing other by products and also the utilization of waste including corn husks. Processed products based on small and medium industries are needed both through small and medium industries. The existence of the processing industry will make agricultural products into products that have added value and high economic value (AM Hasan, et al, 2018: 8) )ii $^{\text {ii }}$ However, the processing carried out is focused on the corn kernels only, while the corn husks have not been processed optimally. In general, people just throw away or burn the waste corn husks that are produced after shelling the corn kernels or making feed ingredients for livestock. Some use of corn husks only as raw material for making flowers. Materials that should be more widely used will provide added value to various aspects of life, especially in the creation of undeveloped handicraft products in Gorontalo. Corn husk processing will provide added value and increase welfare for the people of Gorontalo.

Corn (Zea mays) is one of the world's most important food crops, apart from wheat and rice. Potential source of carbohydrates are corn kernels for food or non-food ingredients (Rukmana, 2012: 15) ${ }^{\mathrm{iv}}$. Corn plants have one or two cobs, depending on the variety. Corn cobs are covered with corn husks, which are called kelobot. Corn cobs that are located on the outside are generally formed earlier and are larger than those on the inside. Each ear consists of 10-16 rows of even seeds.

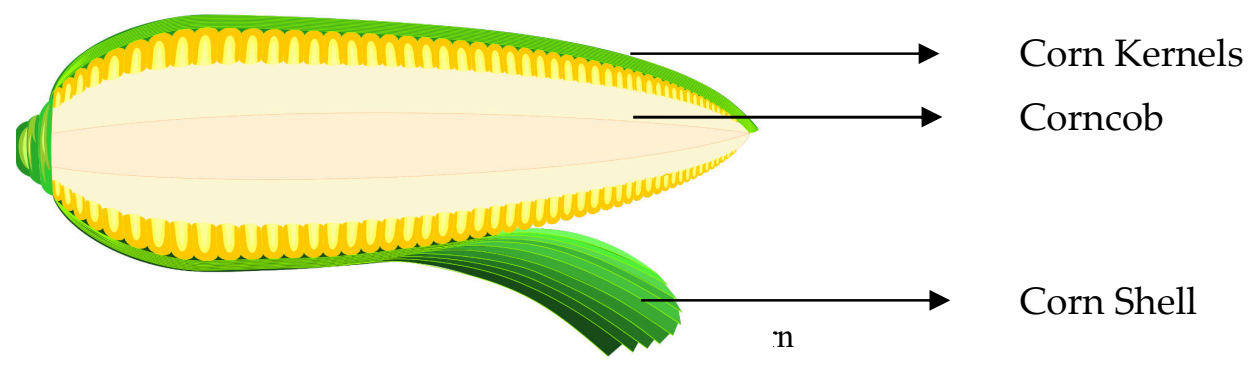

(Source: Research Data, 2020)

In 1 hectare of land measuring 100 meters x 100 meters with a total amount of $10,000 \mathrm{~m}^{2}$, planting is carried out on established plots with a spacing of $75 \mathrm{~cm} \times 25 \mathrm{~cm}$ (http://www.panahmerah.id/guide/budidaya- plant-corn-bonanza ${ }^{\mathrm{v}}$, then in 100 meters there are 40 corn trees $\times 100=4000 \times 3=12,000 \times 10=120,000$ corn husks which will be wasted if not used optimally. These data indicated reasonable to continue to explore the progress of corn and its body so that corn can truly become a superior product for Gorontalo people. ${ }^{\mathrm{vi}}$ 
This research was conducted to find alternative materials for crafts by optimally utilizing corn husk waste to be used as a handycraft product especially wallet products. The results obtained from this processing will be an opportunity to develop handicraft products with the main ingredient of corn husk waste which has become a piece of woven fabric. Fabrics made between vertical yarns (warp yarns) and horizontal yarns (weft threads) on a weaving machine and can be further processed into certain products. ${ }^{\text {vii }}$ Of course this processing will increase the commercial value of corn husk crafts, as well as answer the problem of how to solve the problem of corn husk waste.

\section{Method}

The method used in this research is the experimental method. ${ }^{\text {viii ix }}$ In the early stages of this research, thoughts were made about what should be prepared, to obtain all the images, observations were made either through literature studies, documentation, visits to exhibitions, art galleries or through the search for other supporting data relevant. ${ }^{x}$ After the required data is deemed sufficient, a study is carried out, a literature review from several sources, and considerations to determine which ideas are most likely to be realized in this work in accordance with the idea of fabric and product creation. After the determination of ideas has been determined based on several considerations, several fabric designs are made. Then carried out experimentation on the application of corn husk fibers to woven forms and proceed to craft products. This research process is made in three stages:

1. The first stage is exploration; identification of the characteristics of the corn husk through a Chemical Treatment and tensile strength test ${ }^{\mathrm{xi}}$ by means of strips. ${ }^{\mathrm{xii}}$ The strength of the fiber arrangement is characterized as the capacity of the fiber to withstand tension and strain expressed by the tensile strength. ${ }^{\text {xiii }}$ The formulas used to determine the strength of corn husk fibers is:

Tenacity $(\mathrm{g} / \mathrm{Tex})=$

$$
\text { Bundle Strength (kg) }
$$

\section{Weight in Length (mg)}

The formula for finding the Tenacity number used the tensile strength number of the bundle divided by weight in Length multiplied by 50 . This formula is a commonly used textile fiber test and is a reference guide used by the textile fiber industry.

2. The second stage is design; At this stage, techniques are explored and identified to be used to process the corn husks into handicraft products.

3. The third stage is embodiment; 3 . The third stage is embodiment; namely processing corn husks into handicraft products, especially into wallets.

\section{Results and Discussion} follows:

The results achieved are in accordance with the planned stages and can be described as

\subsection{Exploration Stage}

Corn husks used in this study were sweet corn husks, the reason used is because the skin size of sweet corn husks is wider than other corn husks and the skin of sweet corn is available in greater quantities. Sweet corn, this type of corn is usually harvested and traded in traditional markets while still complete with its skin. The availability of sweet corn in Gorontalo is quite 
abundant, so it is automatically easy to get a large amount of fresh skin. Therefore, in the end, sweet corn husk was chosen which would be processed into a basic material for making crafts.

\subsection{Chemical Treatment of Corn Husk}

The composition of the corn husk sheet consists of several layers which can be grouped into three layers, namely the outer layer, the middle layer and the innermost layer. From several samples of corn husks, it is known that the length and width of the corn husks is between 22-10 centimeters wide and 25-18 centimeters long, with dark green, light green or pale green and white colors.

Table 1. Characteristics of Sweet Corn Skin

\begin{tabular}{cll}
\hline No. & \multicolumn{1}{c}{ Physical properties } & \multicolumn{1}{c}{ Layer } \\
\hline 1 & Corn Skin Layer & Outer layer, midle layer, inner layer \\
2 & Width & $10 \pm 22 \mathrm{~cm}$ \\
3 & Size Length & $18 \pm 25 \mathrm{~cm}$ \\
4 & Color & White, Pale Green, Dark Green \\
5 & Thickness & Thin-Smooth / Thick-rough \\
6 & Flexibility & Flexible / Non-flexible / Hard \\
\hline
\end{tabular}

After soaking for 45 minutes and drying 3 hours with chemicals Acetic acid, ethanoic acid or vinegar have the chemical formula $\mathrm{CH}^{3} \mathrm{COOH}$ is an organic acid chemical compound known to give sour taste and aroma in food. Then there is a change in the appearance of the corn husk to become brighter and its strength increases.

\subsection{Corn husk fiber test}

The corn husk fiber test uses SNI standards 08-1112-1989, with formulas namely how to test tensile and creep strength per bundle.

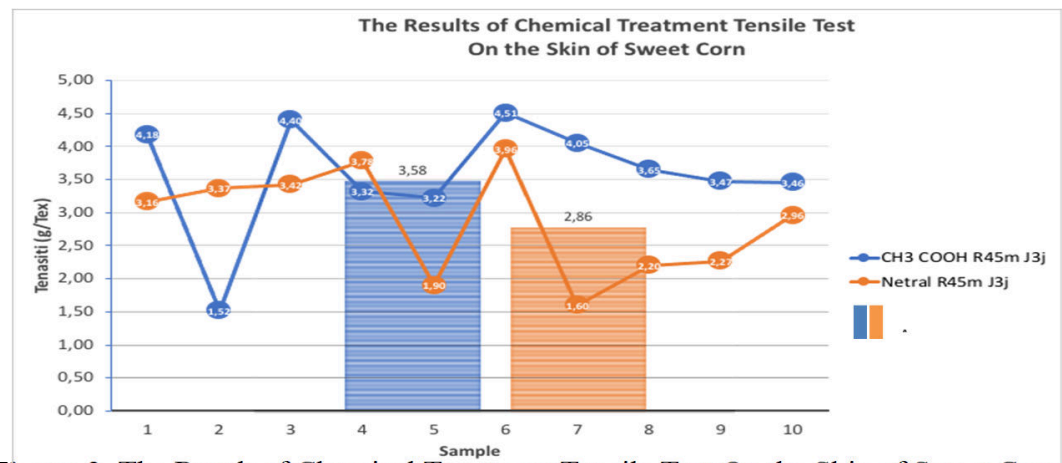

Figure 2. The Result of Chemical Treatment Tensile Test On the Skin of Sweet Corn

The tensile strength test was carried out after giving treatment to the sweet corn husk fibers, namely soaking in plain water and soaking $\mathrm{CH} 3 \mathrm{COOH}$ for 45 minutes and drying for 3 hours. The average figure obtained from ordinary immersion was 2.86 (g/ Tex) and after immersion $\mathrm{CH} 3 \mathrm{COOH}$ the strength increased to 3.86 (g/ Tex). (Fig. 2) 


\subsection{Design Stage}

The activity at this stage was continued by determining the technique for processing corn husks into woven fabric. There are two techniques that were tested, namely:

a. Patchwork or better known as patching technique.

b. The weavings made in this trial use simple looms or non-machine looms (ATBM) with a basic woven structure, namely a cross between two threads that are intertwined perpendicular to each other.

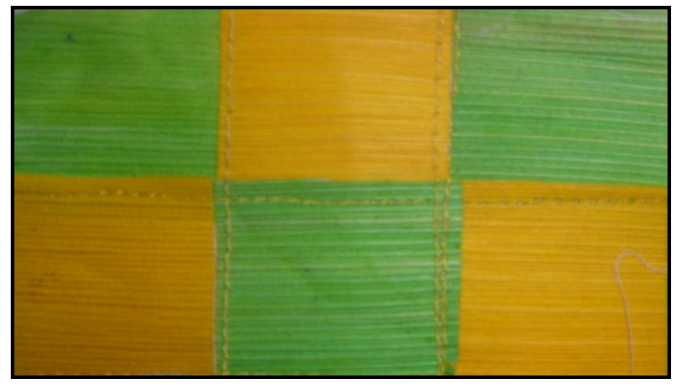

(a) Figure 3. Patcwork

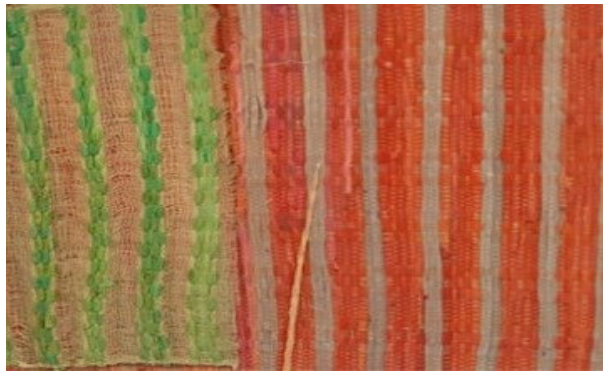

(b) Figure 4. Weaving

The type of weaving is the same as the type of weaving in general, namely the threads are divided into two directions, namely the vertical direction which is called the warp yarn and the horizontal direction which is called the weft thread, only in this tested weft thread in the weave is filled with corn husk material.

\subsection{The Embodiment Stage}

This activity is carried out in several stages, namely:

a) Preparation of tools and materials, b) Preparation of bag patterns, (c) Cutting of corn husk, d) preparation, namely parts and layers that have been cut are arranged according to their respective sizes, e) Sewing process, (f) completion and finishing is useful for strengthening the character and beauty of the wallet, g) product presentation. This is important to note so that the products presented look exclusive.

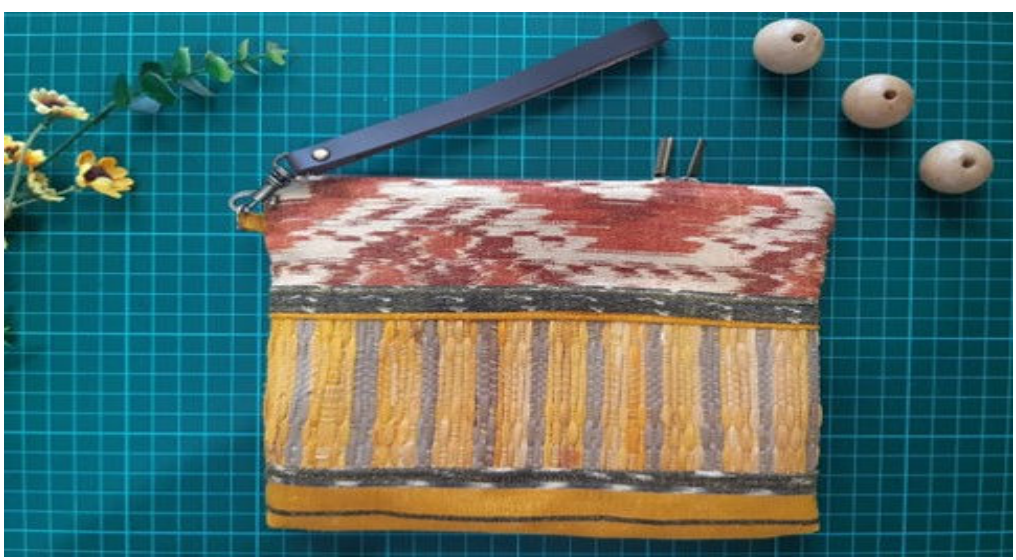

Figure 5. Wallet Made Of Corn Husk Fabric 


\section{Conclusions}

Based on the results of research and discussion it can be concluded that:

(1). The test results showed that there was an increase in the strength of the sweet corn husk fibers after being treated and the color of the corn husks was lighter so that it could be produced into corn husk fabric. (2). Based on the two techniques for making fabrics that were tested, it was determined that the use of the weaving technique was more likely for the raw material for handicraft products, especially for the wallet, when compared to the patchwork technique because the structure of the woven fabric was denser so that the strength was higher. (3). Corn husk fibers can be woven and processed into handicrafts, especially wallets.

\section{References}

[1] BPS Provinsi Gorontalo, 2014, Seri Analisis Pembangunan Wilayah Provinsi Gorontalo.

[2] Halid, Bahuwa, Antuli, \& Abdul, 2017, Distribution development strategy of corn processed (corn stick and corn dodol) production to achieve corn competitive product market in Gorontalo Province, DOI: https://doi.org/10.22437/ppd.v4i4.3802

[3] Hasan, Ani M, Halid, Amir, Hasdiana, 2018, Potensi Pengembangan Produk Olahan Jagung Bagi Kesejahteraan Masyarakat, Ideas Publishing, Gorontalo, p.8. https://repository.ung.ac.id/get/karyailmiah/3314/amir-halid-buku-potensipengembangan-produk-olahan-jagung-bagi-kesejahteraan-masyarakat.pdf

[4] iv Rukmana, Rahmat, 2012, Usaha Tani Jagung, Kanisius, Yogyakarta.

[5] http://www.panahmerah.id/guide/budidaya-tanaman-jagung-bonanza, diakses tanggal 1 November 2020, Pukul 09.55 Wita.

[6] Hasdiana,Hasdiana, Ayuddin, Ayuddin, 2017, Quality Improvement of Corn Husk as Raw Material for Textile Products, Advances in Social Science, Education and Humanities Research (ASSEHR), volume 112, https://doi.org/10.2991/iconhomecs17.2018 .34

[7] Hasdiana, 2017, Buku Ajar; Kriya Tekstil Terapan, Ideas Publishing, Gorontalo. https://www.academia.edu/44558053/Kriya Tekstil Terapan

[8] Raharjo, Timbul, 2013, Penciptaan Seni Kriya: Persoalan dan Model Penciptaan, http://digilib.isi.ac.id/1068/1/page $\% 20$ from $\% 20$ B 15 Penciptaan\%20Seni\%20Kriya\%20Persoalan\%20Model\%20Penciptaan.pdf

[9] Regina, Belinda Dewi, 2018, Implementasi Metode Eksperimen untuk Meningkatkan Prestasi Belajar Menggambar Realis pada Siswa Sekolah Menengah Pertama Negeri 1 Ponorogo, Mudra Jurnal Seni Budaya Vol 33 No 2 (2018): Mei, DOI: https://doi.org/10.31091/mudra.v33i2.256

[10] Gustami, SP, 2004, Proses Penciptaan Seni Kriya "Untaian Metodologis", Program Penciptaan Seni, Pascasarjana Institut Seni Indonesia Yogyakarta.

[11] Dalyono, 2005, Dasar-dasar Perancangan Produk Tekstil, Garaha Ilmu, Yogyakarta.

[12] Hartanto, N.Sugiartono, 1979, Teknologi Tekstil, Association for International Technical Promotion, Tokyo, Japan

[13] Anonymous, 1977, Pengetahuan Barang Tekstil, Institut Teknologi Tekstil, Bandung. 